\title{
вевексн Автіске: Assessment of integrated nutrient management on yield, quality and economics of chilli (Capsicum annuum L.)
}

\section{ם.S. CHOUHAN, SATISH SINGH BAGHEL, KASHYAP MISHRA, AJEET KUMAR SINGH AND VIJAY SINGH}

Article Chronicle: Received :

19.07.2017;

Accepted :

03.08.2017

KeY WoRds :

FYM, Vermicompost, VAM, Azospirillum,

Chilli, Ascorbic acid

Author for correspondence :

SATISH SINGH BAGHEL Jawaharlal Nehru Krishi Viswa Vidyalaya, College of Agriculture, REWA (M.P.) INDIA

Email : rewahortic@ gmail.com

See end of the article for authors' affiliations
SUMMARY : This study was aimed to assess the effects of integrated nutrient management on yield, quality and economics of chilli (Capsicum annuum L.). The present study was carried out during 2012 Rabi season at Research Farm, J.N.K.V.V. College of Agriculture, Tikamgarh, (M.P.), India with 10 treatment combinations $\left(\mathrm{V}_{1} \mathrm{I}_{1} \cdot \mathrm{V}_{1} \mathrm{I}_{2}, \mathrm{~V}_{1} \mathrm{I}_{3} \mathrm{~V}_{1} \mathrm{I}_{4} \mathrm{~V}_{1} \mathrm{I}_{5}, \mathrm{~V}_{2} \mathrm{I}_{1} \mathrm{~V}_{2} \mathrm{I}_{2} \mathrm{~V}_{2} \mathrm{I}_{3} \mathrm{~V}_{2} \mathrm{I}_{4} \mathrm{~V}_{2} \mathrm{I}_{5}\right.$ wheres $\mathrm{V}_{1}-$ Pusa Jwala, V $\mathrm{V}_{2}$ Garima -12 and INM facors, $I_{1}$ - recommended dose of fertilizer (RDF) or Control (100:50:50 kg NPK ha$\left.{ }^{1}\right), I_{2-}$ RDF + FYM (10 t ha $\left.{ }^{-1}\right), I_{3}-R D F+$ Vermicompost $\left(2.5 \mathrm{t} \mathrm{ha}^{-1}\right), \mathrm{I}_{4}-\mathrm{RDF}+$ Vesicular arbuscular mycorrhiza (VAM) @ $2 \mathrm{~kg} \mathrm{ha}^{-1}, \mathrm{I}_{5}-\mathrm{RDF}+$ Azospirillum in Factorial Randomized Block Design with 3 replications. Application of RDF + Vermicompost 2.5 tonnes ha ${ }^{-1}$ showed significant increase in fruit yield plant ${ }^{-1}(271.5 \mathrm{~g})$ and fresh fruit yield of $6816 \mathrm{~kg} \mathrm{ha}^{-1}$.Significantly the lowest fruit yield plant ${ }^{-1}$ and fresh fruit yield of chilli (227.8 $\mathrm{g}$ and $4218 \mathrm{~kg} \mathrm{ha}^{-1}$, respectively) was noticed in recommended dose of fertilizer (RDF) or Control (100:50:50 kg NPK ha ${ }^{-1}$ ). Combined application of RDF + Vermicompost 2.5

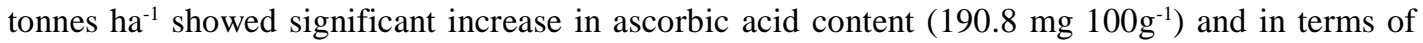
benefit cost ratio was economical with highest net returns (181607 Rs. ha ${ }^{-1}$ ) and B:C (3.19). However

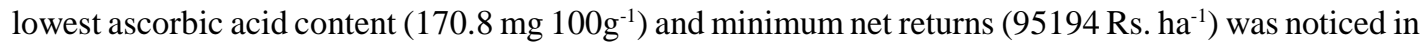
control (100:50:50 kg NPK ha-1) while, minimum B:C ratio (3.19) with $\mathrm{I}_{2}$.

How to cite this article : Chouhan, K.S., Baghel, Satish Singh, Mishra, Kashyap, Singh, Ajeet Kumar and Singh, Vijay (2017). Assessment of integrated nutrient management on yield, quality and economics of chilli (Capsicum annuum L.). Agric. Update, 12(TECHSEAR-7) : 1978-1982; DOI: 10.15740/HAS/AU/12.TECHSEAR(7)2017/ 1978-1982. 